\title{
PENGARUH VISUAL PACKAGING DESIGN (WARNA, BENTUK, UKURAN) DAN PACKAGING LABELING (KOMPOSISI, INFORMASI NILAI GIZI, KLAIM) TERHADAP PURCHASE INTENTIONS PRODUK MAKANAN DAN MINUMAN DALAM KEMASAN DI JAKARTA
}

\author{
Elfa Karin Parassih \\ Program Studi Magister Manajemen Univesitas Tarumanagara \\ elfa.karin8@gmail.com \\ Eko Harry Susanto \\ Program Studi Magister Manajemen Universitas Tarumanagara
}

Masuk : 28-05-2020, revisi : 24-06-2020 diterima untuk diterbitkan : 25-06-2020

\begin{abstract}
This study aims to determine the effect of visual packaging design consisting of color, shape, and size and packaging labeling consisting of composition, nutritional value information, and claims on purchase intention of pre-packaged food products. The method used is a descriptive method with a quantitative approach. The research period was conducted in April 2020 with 200 respondents using linear regression analysis. The results of this study indicate that visual packaging design and packaging labeling significantly influence the purchase intention of packaged food products at a significance level of 0.05 . The regression equation that is formed from the results of this study is $\mathrm{Y}=3.487+1.323 \mathrm{X}_{1}+0.677 \mathrm{X}_{2}$. Companies can focus more on developing packaging designs and delivering product information such as information on composition, nutrition, and product claims accompanied by scientific evidence.
\end{abstract}

Keywords : Visual Packaging Design, Packaging Labeling, Pre-Packaged Food Products, Purchase Intention

\begin{abstract}
Abstrak : Penelitian ini bertujuan untuk mengetahui pengaruh visual packaging design yang terdiri atas warna, bentuk, dan ukuran serta packaging labeling yang terdiri atas komposisi, informasi nilai gizi, dan klaim terhadap purchase intention produk makanan dan minuman dalam kemasan. Metode yang digunakan adalah metode deskriptif dengan pendekatan kuantitatif. Periode penelitian dilakukan pada bulan April 2020 dengan responden sebanyak 200 orang. Penelitian ini menggunakan analisis regresi linear. Hasil dari penelitian ini menunjukkan bahwa visual packaging design dan packaging labeling secara signifikan berpengaruh terhadap purchase intention produk pangan dalam kemasan pada level signifikansi 0.05 . Persamaan regresi yang terbentuk dari hasil penelitian ini adalah $\mathrm{Y}=3,487$ $+1,323 X 1+0,677 X 2$. Perusahaan dapat lebih fokus dalam pengembangan desain kemasan dan penyampaian informasi produk seperti informasi komposisi, nutrisi, dan klaim yang bertanggung jawab disertai dengan bukti-bukti ilmiah.
\end{abstract}

Kata Kunci : Visual Packaging Design, Packaging Labeling, Produk Pangan dalam Kemasan, Purchase Intention

\section{PENDAHULUAN}

Keberhasilan suatu perusahaan sebagian besar tergantung pada kemampuannya untuk menarik konsumen ke dalam merek yang mereka jual (Kotler \& Keller, 2016). Oleh karena itu, loyalitas merek mereka sangat penting untuk kelangsungan hidup perusahaan. Kemasan produk merupakan salah satu hal yang dapat memengaruhi loyalitas karena mempengaruhi keputusan pembelian konsumen secara substansial. Kemasan dapat menjadi alat komunikasi antara produsen dan konsumen melalui desain produk dalam bentuk logo, gambar, tulisan, dan 
informasi produk. Berdasarkan penelitian (Keller, 2012) di dalam minimarket atau supermarket rata-rata berisi 20.000 produk yang saling bersaing untuk menarik perhatian konsumen. Konsumen akan menghadapi beberapa pilihan pada saat berbelanja, sebelum akhirnya membuat keputusan pembelian. (Rettie \& Brewer, 2000) menyatakan bahwa 73\% konsumen membuat keputusan pada saat titik penjualan, dimana kemasan seringkali menjadi keputusan terakhir dalam membeli produk (Nawaz, et al., 2012). Dengan demikian, kemasan produk dianggap sebagai alat pemasaran yang kuat yang dapat dimanfaatkan oleh pemasar untuk mempromosikan produknya (Keller, 2012). Label kemasan yang baik bersifat benar atau asli dan tidak menyesatkan (BPOM, 2018). Berdasarkan data dari The Nielsen Company (2017), dalam kondisi konsumsi saat ini, ada keinginan konsumen untuk mendapatkan pemahaman lebih tentang bahan dan nutrisi pada suatu produk. Minat pembelian atau purchase intention adalah tahap kecenderungan konsumen untuk bertindak sebelum keputusan membeli benarbenar dilaksanakan. Dalam purchase intention konsumen memiliki kemungkinan untuk membeli suatu produk atau layanan di masa depan. Berdasarkan (Bian \& Moutinho, 2011), purchase intention diartikan sebagai kemungkinan pembeli bermaksud untuk membeli produk yang secara positif berhubungan terhadap persepsi keseluruhan pada akuisisi dan transaksi nilai. Purchase intention dapat terjadi karena adanya pencocokan motif pembelian dengan atribut atau karakteristik merek yang dipertimbangkan. Oleh karena itu, purchase intention akan muncul setelah seorang calon konsumen melakukan evaluasi terhadap suatu produk atau jasa (Kotler \& Armstrong, 2012).

\section{TINJAUAN PUSTAKA \\ Visual Design Packaging}

Kemasan produk didefinisikan sebagai semua kegiatan merancang dan memproduksi wadah yang melindungi serta menjual suatu produk (Kotler dan Keller, 2016). Kemasan adalah titik akhir komunikasi antara suatu merek dan konsumen pada saat berbelanja. Sebagai alat komunikasi pemasaran, kemasan harus dapat mengirimkan pesan kepada konsumen melalui desainnya. Menurut (Klimchuk \& Krasovec, 2007). Berdasarkan Smith dan Taylor (2004), terdapat enam variabel yang harus dipertimbangkan oleh produsen saat membuat kemasan yang efisien, yaitu: bentuk, ukuran, warna, grafik, bahan, dan rasa. Sedangkan Kotler (2012) membahas enam elemen lainnya, yaitu ukuran, bentuk, bahan, warna, teks, dan merek. Elemenelemen tersebut harus dievaluasi dalam pertimbangan memilih kemasan produk. Silayoi dan Speece $(2004,2007)$ membagi desain kemasan menjadi dua elemen: elemen visual (bentuk, ukuran, grafik, dan warna) dan elemen informasi (informasi yang dicantumkan). Elemen visual, memuat aspek afektif dari proses pengambilan keputusan konsumen, sementara elemen informasi berhubungan dengan elemen kognitif. Elemen-elemen visual sangat penting karena pengaruh yang mereka miliki terhadap emosi target pasar.

\section{Packaging Labeling}

Label pangan adalah suatu komponen penting dalam suatu industri untuk memasarkan produknya karena memiliki pengaruh kuat pada keputusan pembelian konsumen. Label pangan dapat secara langsung mempengaruhi keputusan pembelian karena dapat mendorong mereka untuk menerima informasi mengenai suatu produk. Label pangan disebut sebagai suatu media dimana konsumen dapat memperoleh pengetahuan atau Informasi mengenai makanan yang akan mereka beli atau konsumsi. Dalam pencantumannya, label pangan diatur melalui lembaga dalam negara untuk menjaga keamanan pangan di negara tersebut. Di Indonesia, label pangan diatur oleh lembaga/balai POM (Pengawasan Obat dan Makanan). Menurut BPOM, Label Pangan Olahan adalah setiap keterangan mengenai Pangan Olahan yang berbentuk gambar, tulisan, kombinasi keduanya, atau bentuk lain yang disertakan pada Pangan Olahan, dimasukan ke dalam, ditempelkan pada, atau merupakan bagian Kemasan Pangan (BPOM, 2018). 


\section{Purchase Intention}

Menurut Schiffman dan Kanuk (2014), "purchase intention dapat mengukur kemungkinan konsumen membeli suatu produk, dan semakin tinggi purchase intention yang dimiliki seseorang maka semakin tinggi kesediaannya untuk membeli produk". Dari definisi yang sudah disebutkan, maka pada penelitian ini, purchase intention didefinisikan sebagai suatu keinginan seseorang untuk melakukan transaksi. Pada saat tahapan pembelian, terdapat dua faktor yang dapat muncul diantara purchase intention dan purchase decision, yaitu attitude of others dan unexpected situational factors (Kotler \& Armstrong, 2012).

Berdasarkan dasar teori diatas, maka Hipotesis penelitian adalah sebagai berikut:

$\mathrm{H}_{1}$ : Terdapat hubungan positif antara Visual Design Packaging (warna, bentuk, ukuran, gambar) terhadap Purchase Intention produk makanan dan minuman dalam kemasan.

$\mathrm{H}_{2}$ : Terdapat hubungan positif antara Packaging Labeling (komposisi, informasi nilai gizi, klaim) terhadap Purchase Intention produk makanan dan minuman dalam kemasan.

\section{METODE PENELITIAN}

Metode yang digunakan adalah metode deskriptif dengan pendekatan kuantitatif. Periode penelitian dilakukan pada bulan April 2020 dengan responden sebanyak 200 orang. Kuesioner berisi 19 pertanyaan untuk mengukur variabel bebas dan variabel terikat. Variabel bebas dalam penelitian ini terdiri dari Visual Packaging Design (warna, bentuk, ukuran) dan Packaging Labeling (komposisi, informasi nilai gizi, klaim produk). Sedangkan variabel terikat adalah minat pembelian atau purchase intention. Skala pengukuran dalam kuesioner yaitu skala Likert yang terdiri atas 5 titik, 1 menerangkan sangat tidak setuju atas pernyataan kuesioner, dan 5 menyatakan sangat setuju pada pernyataan kuesioner. Data yang terkumpul antara lain adalah perempuan (74\%) dan 52 laki-laki (26\%) dengan usia 20-27 tahun sebanyak 146 orang (73\%). Sebagian responden bekerja sebagai karyawan atau pegawai swasta $(58 \%)$ dengan tingkat pendidikan tertinggi S1/Sederajat (71\%).

Hasil uji validitas menunjukkan tiga indikator variabel Visual Packaging Design, enam indikator variabel packaging labeing, dan sembilan indikator variabel purchase intention valid karena nilai $\mathrm{r}$ hitung (corrected item-total correlation) lebih besar daripada $\mathrm{r}$ tabel $(0,138)$. Uji reliabilitas juga menunjukkan bahwa nilai Cronbach's Alpha dari ketiga variabel penelitian lebih besar daripada 0,60 sehingga ketiga variabel penelitian tersebut reliabel.

\section{HASIL DAN PEMBAHASAN}

Responden penelitian ini terdiri dari orang-orang yang mengisi kuisioner secara online dan yang memiliki pengalaman dan memperhatikan kemasan makanan atau minuman dalam kemasan seperti produk dairy, makanan ringan, biskuit, keripik, makanan instan, minuman dalam botol atau kaleng, makanan diet, dan lainnya. Responden juga diukur berdasarkan frekuensi pembelian produk dan produk pangan yang paling sering dibeli, terdapat dua parameter utama yaitu responden yang membeli produk pangan selama kurang dari tiga kali dalam seminggu sebanyak $42 \%$ dan responden yang membeli produk lebih dari tiga kali seminggu sebanak 55\%. Berdasarkan data yang terkumpul terdapat $68 \%$ paling sering membeli produk berupa snack, kemudian 57\% responden membeli makanan instan, pembelian produkproduk dairy sebanyak 54\%, minuman dalam kemasan (botol atau kaleng) sebanyak 49\%, biskuit $38 \%$, snack diet sebanyak $6 \%$, dan lainnya $1 \%$.

Berdasarkan hasil uji t pada Tabel 1, maka diperoleh persamaan regresi sebagai berikut $\mathrm{Y}=\mathrm{a}+\mathrm{b} 1 \mathrm{x} 1+\mathrm{b} 2 \mathrm{x} 2+\mathrm{e}$, dimana $\mathrm{Y}=3,487+1,323 \mathrm{X} 1+0,677 \mathrm{X} 2$. Berdasarkan persamaan tersebut dapat dilihat bahwa visual packaging design lebih mempengaruhi purchase intention dibandingkan dengan packaging labeling. 
Tabel 1

Analisis Regresi Linear Berganda

\begin{tabular}{|c|c|c|c|}
\hline Hipotesis & Koefisien & Nilai t & p values \\
\hline $\begin{array}{c}\text { Visual packaging design terhadap Purchase } \\
\text { intention }\end{array}$ & 1,323 & $10,692 *$ & 0,00 \\
\hline $\begin{array}{l}\text { Packaging labeling terhadap Purchase } \\
\text { intention }\end{array}$ & 0,677 & $11,617 *$ & 0,00 \\
\hline
\end{tabular}

$\mathrm{H}_{1}$ diterima berarti terdapat pengaruh positif antara visual packaging design terhadap purchase intention produk pangan dalam kemasan. Hasil menunjukkan bahwa visual design packaging yang terdiri dari warna kemasan, bentuk kemasan, dan ukuran kemasan berpengaruh secara signifikan terhadap purchase intention. Hal ini sesuai dengan penelitian yang dilakukan oleh Salem (2018) yang menyebutkan bahwa visual design packaging akan membantu penjualan sebagai "silent sales/marketers" dan memiliki hubungan positif untuk mendorong keputusan pembelian konsumen. Penelitian yang dilakukan oleh Farooq, Habib, dan Aslam (2015) juga menunjukkan bahwa empat elemen kemasan (desain, gambar, warna, dan bahan) secara signifikan mempengaruh minat beli konsumen. Terbukti bahwa kemasan suatu produk memiliki kekuatan marketing dan mempengaruhi kesan pertama lewat bahasa non-verbalnya. Konsumen cenderung melirik terlebih dahulu bentuk visual kemasan sebelum mempelajari komponen yang terkandung dalam suatu produk. Kotler dan Keller (2016) menyatakan bahwa warna, bentuk, ukuran, dan lainnya merupakan elemen yang sangat penting dalam kemasna produk. Warna mempengaruhi emosi dan perasaan konsumen, misalnya munculnya asosiasi positif akibat melihat warna tertentu (Deliya \& Parmar, 2012). Warna juga menjelaskan kesegaran, kualitas, dan modernisasi suatu desain kemasan sehingga memiliki peran besar untuk menarik perhatian konsumen. Lebih lanjut, bentuk kemasan juga merupakan salah satu komunikasi pemasaran secara non-verbal dari perusahaan kepada para konsumen. Bentuk secara visual lebih mudah dideskripsikan dibandingkan rasa ataupun aroma, hal ini dapat menjadi alasan pentingnya kesan visual suatu produk. Perasaan yang ditimbulkan oleh kesan pertama selama beberapa detik biasanya menentukan apakah pelanggan akan membeli produk tersebut atau bahkan tidak tertarik dengan produk tersebut (Deliya dan Parmar, 2012).

Dari Tabel 1 dapat dilihat bahwa hipotesis $\mathrm{H}_{2}$ diterima, yaitu terdapat pengaruh positif antara packaging labeling terhadap purchase intention produk pangan dalam kemasan. Komposisi merupakan bagian dalam informasi produk yang dijelaskan pada kemasan secara verbal atau tertulis. Fokus konsumen pada pembacaan label kemasan pangan adalah untuk menghindari komponen-komponen dalam produk yang dapat membahayakan kesehatan, misalnya alergen. Beberapa konsumen memiliki kehati-hatian dalam pemilihan produk yang mengandung susu, telur, kacang, seafood, dan bahan alergen lainnya sehingga cenderung terlebih dahulu membaca komposisi. Lebih lanjut, beberapa konsumen sensitif terhadap komponen pangan yang mengandung BTP (bahan tambahan pangan) seperti pengawet, pemanis buatan, perisa sintetik, dan lain sebagainya. Fokus selanjutnya dalam informasi product labeling adalah informasi nilai gizi atau nutrition facts. Informasi tersebut dapat menciptakan persepsi kesehatan bagi konsumennya. Saat ini Indonesia sendiri sedang "berperang" mengatasi isu GGL (Gula, Garam, dan Lemak) untuk mengurangi risiko penyakit tidak menular. Berdasarkan anjuran Kementerian Kesehatan RI tahun 2019 batas konsumsi GGL dalam seluruh asupan makanan per hari secara berurutan adalah 54 gram gula, 2000mg natrium atau garam, dan 72 gram lemak. Selanjutnya, produk klaim dapat menjadi pertimbangan konsumen, yaitu klaim "Organik", "Natural", "Produk pilihan lebih sehat" maupun klaim-klaim gizi dan kesehatan seperti "Kaya akan Serat Pangan", "Tinggi Vitamin dan Mineral", "Tinggi Kalsium", dan lain sebagainya. Klaim organik pada produk mempengaruhi pilihan konsumen dalam menentukan apa yang hendak mereka konsumsi, namun knowledge konsumen terhadap pangan berlogo organik masih kurang. Konsumen pada umumnya memilih logo "organik" dengan alasan hanya lebih baik dari produk lainnya, 
sehingga perlu dilakukan edukasi konsumen mengenai klaim tersebut (Teng \& Wang, 2015). Berdasarkan (Petrovici, et al., 2012) terdapat beberapa faktor yang mempengaruhi penggunaan klaim gizi dan kesehatan pada produk pangan, antara lain product class involvement, karakteristik individu, faktor yang berhubungan dengan kesehatan (pengetahuan akan nutrisi, kontrol kesehatan, kebutuhan yang dirasakan akan perubahan pola makan), dan faktor perilaku. Klaim kesehatan membutuhkan nilai kepercayaan konsumen bahwa klaim yang di cantumkan benar adanya dan sesuai dengan kajian ilmiah yang dilakukan oleh produsen. Hal ini juga ditemukan oleh Petrovici, et. al (2012) bahwa terdapat bukti ketidakpercayaan konsumen terhadap klaim yang tercantum disebabkan oleh faktor pengetahuan dan pendidikan konsumen.

Minat pembelian atau purchase intention dalam penelitian ini dipengaruhi oleh dua hal yang paling utama dalam menarik perhatian konsumen. Pertama, visual design packaging yang terdiri atas warna, bentuk, serta ukuran kemasan mempengaruhi kesan pertama terhadap suatu produk. Penelitian ini sejalan dengan penelitian sebelumnya yang dilakukan oleh Baruk dan Iwanicka (2016) dan Salem (2018) yang menyatakan bahwa fitur-fitur kemasan seperti warna, bentuk, ukuran, dan gambar mempengaruhi keputusan pembelian konsumen. Sedangkan product labeling yang terdiri atas komposisi, ING, dan klaim mempengaruhi keputusan pembelian konsumen (Kumar dan Kapoor, 2017; Ha dan Dung, 2017).

\section{KESIMPULAN}

Dari penelitian ini dapat disimpulkan bahwa visual packaging design yang terdiri atas warna, bentuk, dan ukuran kemasan memiliki pengaruh positif terhadap purchase intention konsumen pada produk makanan dan minuman dalam kemasan. Selain itu, packaging labeling yang terdiri atas komposisi, informasi nilai gizi, dan klaim produk memiliki pengaruh positif terhadap purchase intention konsumen pada produk makanan dan minuman dalam kemasan. Peran pemerintah sebagai regulator menjadi sangat penting untuk dapat melimitasi perusahaan dan melindungi konsumen dari misinterpretasi serta menjaga kesehatan masyarakat Indonesia. Edukasi kepada masyarakat akan peran kemasan serta informasi kemasan dalam pembelian produk pangan merupakan hal yang penting, industri sebagai produsen juga memiliki tanggung jawab dalam hal ini.

\section{REFERENSI}

Bandara, B., De Silva, D. A., Maduwanthi, B., \& Warunasinghe, W. I. (2016). Impact of Food Labeling Information on Consumer Purchasing Decision : With Special Reference to Faculty of Agricultural Sciences. Procedia Food Science, 6 (2016), 309 - 313.

Baruk, A., \& Iwanicka, A. (2016). The Effect of Age, Gender and Level of Education on The Consumer's Expectations towards Dairy Product Packaging. British Food Journal, 118 (1), 100-118.

Bian, X., \& Moutinho, L. (2011). The Role of Brand Image, Product Involvement, and Knowledge in Explaining Consumer Purchase Behaviour of Counterfeits : Direct and Indirect Effects. European Journal of Marketing, 45 (1/2), 191-216.

BPOM (Badan Pengawasan Obat dan Makanan). (2018). PerKa BPOM no. 31 tahun 2018 tentang Label Pangan Olahan. BPOM.

Deliya, M., \& Parmar, B. (2012). Role of Packaging on Consumer Buying Behavior. Global Journal of Management and Business Research, 12 (10), 48-68.

Farooq, S., Habib, S., \& Aslam, S. (2015). Influence of Product Packaging on Consumer Purchase Intentions. International Journal of Economics, Commerce and Management, 3 (12), 538-547.

Ha, Nguyen. M., \& Dung, Nguyen. T. (2017). To Study Consumers' Use of Information on Food Labels in Vietnam. International Review of Management and Marketing, 7 (1), 175-182.

Keller, K. (2012). Strategic Brand Management (4 ${ }^{\text {th }}$ ed.). Pearson Education, Harlow. 
Kementerian Kesehatan RI. (2019, Oktober). Batasi Gula, Garam, Lemak. Retrieved Mei 2020, from http://p2ptm.kemkes.go.id/infographic-p2ptm/hipertensi-penyakit-jantungdan-pembuluh-darah/batasi-gula-garam-lemak

Klimchuk, M. R., \& Krasovec, S. A. (2007). Desain Kemasan : Perencanaan Merek Produk yang Berhasil Mulai dari Konsep sampai Penjualan (Bob Sabran, Penerjemah.). Jakarta : Erlangga.

Kotler, P., \& Amstrong, G. (2012). Principles of Marketing (14 ${ }^{\text {th }}$ ed.). Essex: Pearson Education Limited.

Kotler, P., \& Keller, K. L. (2016). Marketing Management (15 ${ }^{\text {th }}$ ed.). Pearson.

Kumar, N., \& Kapoor, S. (2017). Do Labels Influence Purchase Decisions of Food Products? Study of Young Consumers of an Emerging Market. British Food Journal, 119 (2), 218 -229 .

Nawaz, A., Billoo, M., \& Lakhan, A. (2012). Effect of Product Packaging in Consumer Buying Decision. Journal of Business Strategies, 6 (2), 1-10.

Petrovici, D., Fearne, A., Nayga, R., \& Drolias, D. (2012). Nutritional Knowledge, Nutritional Labels, and Health Claims on Food : A Study of Supermarket Shoppers in The South East of England. British Food Journal, 114 (6), 768-783.

Rettie, R., \& Brewer, C. (2000). The Verbal and Visual Components of Package Design. Journal of Product Brand Management, 9 (1), 56-70.

Salem, M. Z. (2018). Effects of Perfume Packaging on Basque Female Consumers Purchase Decision in Spain. Management Decisions, 56 (8), 1748-1768.

Silayoi, P., \& Speece, M. (2004). Packaging and Purchase Decisions : An Exploratory Study on The Impact of Involvement Level and Time Pressure. British Food Journal, 106 (8), 607-628.

Silayoi, P., \& Speece, M. (2007). The Importance of Packaging Attributes : A Conjoint Analysis Approach. European Journal of Marketing, 41 (11/12), 1495-1517.

Smith, P., \& Taylor, J. (2004). Marketing Communications : An Integrated Approach (4 ${ }^{\text {th }}$ ed.). London.

Teng, C.C., \& Wang, Y.M. (2015). Decisional Factors Driving Organic Food Consumption: Generation of Consumer Purchase Intentions. British Food Journal, 117 (3), 1066-1081.

The Nielsen Company. (2017). Nielsen Delivers Transparency to Food Labeling Data. Retrieved from Press Releases: https://www.nielsen.com/us/en/pressreleases/2017/nielsen-delivers-transparency-to-food-labeling-data/

USDA Foreign Agricultural Service. (2019). Indonesia Retail Foods Update. GAIN USDA. 